Ankara Üniversitesi

SBF Dergisi,

Cilt 71, No. 4, 2016, s. 1033 - 1058

\title{
TROUBLED FUTURE FOR THE UNITED NATIONS [UN] USE OF FORGE AND PEACE OPERATIONS
}

\author{
Yrd. Doç. Dr. Ali Bilgin Varlık \\ İstanbul Esenyurt Üniversitesi \\ İşletme ve Yönetim Bilimleri Fakültesi
}

\begin{abstract}
The purpose of this article is to examine the hindrances of the UN's use of force and peace operations. Analyzing shortfalls which affect the UN's capacity at this context requires systemic, structural, institutional and conjunctural assessments. Considering cause and result relations one can easily reach to the conclusion that there is an imbalance on applying use of force and peace operations. Unless the UN preserves the delicate balance between sovereignty rights of the states and human rights, and principles of international law, reforms at the technical, tactical or operational levels has little to meet expectations. The UNSC's dominant role on decision making process, political struggle between global powers, and systemic problems such as limitations of complementary institutions, failure of collective defence, and operational deficiencies, hinder the capacity of the UN's use of force and peace operations. Current balance of power which is highly different both from the settings of the Cold War and 1990s while stagnating use of force applications overburdens peace operations. This situation obliges the UN to manage conflicts with less appropriate tools. Hence there is need for a renewed focus on peace and security issues with a stronger determination of the UN with extensive coordination and cooperation.
\end{abstract}

Keywords: UN, Peace Operations, Use of Force, Peace Keeping, Operations Other Than War

Birleşmiş Milletler (BM) Kuvvet Kullanma ve Barış Harekâtının Sorunlu Geleceği

\section{Öz}

Bu makalenin amacı, BM'nin kuvvet kullanma ve barıs operasyonlarının sınırlılıklarını incelemektir. BM'nin bu kapsamdaki kısıtlarını analiz etmek, sistemik, yapısal, kurumsal ve devri değerlendirmeleri gerektirir. Neden ve sonuç ilişkilerine bakıldığında, kuvvet kullanma ve barış harekâtı uygulamaları arasında bir dengesizlik olduğu sunucuna kolaylıkla ulaşılabilir. BM devletin egemenlik hakları ile insan hakları ve uluslararası hukukun ilkeleri arasındaki hassas dengeyi muhafaza etmedikçe, teknik, taktik ve operasyonel seviyede gerçekleştirilen reformlar beklentilerin çok az bir kısmını karşılayabilir. BM'nin karar süreçlerindeki belirleyici rolü, küresel güçler arasındaki politik çekişme ve bütünleyici kurumların yetersizliği, kolektif savunmada başarısızlık ve harekât kısıtları gibi sistemik sorunlar BM'nin kuvvet kullanma ve barış operasyonu kapasitesini kısıtlamaktadır. Soğuk Savaş'tan ve 1900'lardan çok farklı olan cari güç dengesi, bir taraftan kuvvet kullanma imkanlarını kısıtlarken diğer taraftan barış operasyonlarına fazlasıyla yüklenmektedir. Bu durum BM'yi, çatışmaları uygun olmayan vasıtalarla yönetmeye zorlamaktadır. Bu yüzden BM'nin, kapsamlı işbirliği ve koordinasyonla, barış ve güvenlik meselelerine daha güçlü bir kararlılıkla yenilenmiş bir odaklanmaya ihtiyacı vardır. Harekât

Anahtar Sözcükler: BM, Barış Operasyonları, Kuvvet Kullanma, Barışı Koruma, Savaş Dışı

* Makale geliş tarihi: 21.01.2016

Makale kabul tarihi: 16.05.2016 


\section{Troubled Future for the United Nations (UN) Use of Force and Peace Operations ${ }^{1}$}

\section{Introduction}

This paper examines the obstacles to effective use of force and peace operations by the UN over time. The main argument of the study is that the structural, systemic, and functional shortfalls of the UN, combined with tensions spurred from the political and security conjuncture will complicate and undercut the organisation's future security initiatives. The complementary argument of the paper is that unless the UN strikes a proper balance between the use of force and peace operations, and adjusts its approach to evolving conditions, planned enhancements may provide limited benefits. The analysis shows that some of the suggestions currently contemplated as "silver-bullets" to improve the UN current and future use of force and peace operations may not yield the desired results.

The body of the study is comprised of three main sections: a theoretical framework for the UN use of force and peace initiatives, an analytical evaluation of UN operations within the theoretical context, and a general assessment.

In the first section, the legitimacy of force and peace operations are discussed within the UN Charter. In this context, the complicating factors of competing political and judicial approaches -moralist versus realist, conservative versus reformist -are broadly mentioned. In this section the structural characteristics and the actual practices of the states, which decisively effect UN operations' success, are also scrutinised. The conceptual framework drawn in this section gives basic parameters of the problematic structure governing UN use of force and peace operations, and also addresses interrelated issues between main bodies of the $\mathrm{UN}$ and its associated organisations.

Secondly, an analytical and descriptive picture of the UN's use of force and peace operations is drawn by quantitative, categorical, and trend changes over time. Additionally, functional and procedural shortfalls which either collectively or individually contribute to the UN's operational inadequacy for the establishment of sustainable peace are discussed.

1 This article is the enhanced version of the paper (of 4.000 words) submitted at Istanbul Security Conference (03-05 December 2015). 
The final section deals with an assessment of structural, functional, and conjectural dynamics related to current and potential UN use of force and peace initiatives, based upon anticipated future developments. This section also examines the acceptability, adequacy, efficiency, and applicability of current proposals for improving UN operations, as well as the relationship and mutual influence between the distinct but related phenomena of use of force and peace initiatives.

\section{Theoretical Framework}

\subsection{The Premise of the $U N$ and the Debate between the Conventional versus Reformist, and the Realist versus Moralist Approaches}

The traditional international view of war as a legitimate tool that states may resort to in pursuit of their national interest was upended by the new paradigm set at San Francisco Conference held from April 25-June 26, 1945. With one exception -in the preamble- the word war does not appear in the UN Charter. Since the main premise of the UN Charter, is to save "succeeding generations from the scourge of war," the right to use force was to be reserved only for the UN, with the sole exception being the "inherent right of selfdefence in case of an armed attack (article 51)".

The UN was founded on the premise of the need for an organization to sustain international security, and the founding conference opened up a discussion on how this goal will be achieved. Based up on the principle of not violating the sovereign rights of the individual states (Art. 2/7), the prevailing approach favored stability, while a minority of reformists argued that human rights, and justice-based approach was necessary for sustainable peace. This debate also reflected realist versus moralist arguments. As more member nations have joined the UN, views have evolved and today the majority of the members of the General Assembly (UN GA) support moralist and reformist change. Such change would erode the UN Security Council (UNSC) authority. The UNSC has traditionally placed a premium on managing or avoiding major power confrontation and the escalation of minor conflicts; the UNSC permanent members prefer stability and preservation of the status quo to revisions and moralist arrangements that run contrary to the existing balance of power.

Arguments between proponents of the respective approaches have been numerous, and two key factors have shaped the outcome of such struggles: the structural characteristics of the UN and the actual practice of the states. The dominant powers represented on the UNSC have determined the first of these, 
the conjunctural global balance of power has shaped the second, and systemic shortfalls and challenges have modified them both.

The UN's primary goal which prioritizes international stability and puts more emphasis on state sovereignty on the expense of human rights and justice, has narrowed area of initiatives for sustainable peace. This approach which is realistic in nature, has shaped not only institutions for use of force and peace operations -mentioned in the following section (1.4.1.) but also force structure. Dominant states' -mostly members of the UNSC- preferences which generally fit into realist paradigm, shape modalities of conduct such as concept of operation, military goals and desired end-states.

Together with the world order, realists' devastating influence has long framed the context of use of force and peace operations. For most of the period between the late 1940s to the 1980s -with the exception of the first Congo operations which also contains police force (Boulden, 2015: 160)- the objectives of the UN peacekeepers tended to focus on preserving international security, no matter how the peace established was fragile, and main issues were swept under the carpet. Particularly after the Cold War, intense contribution of regional organizations (UNRO) to peace operations could have helped to promote moralist approach with broadened objectives of UN operations, if UNROs were not in the hands or under the control of "dominant states".

On the other hand, there are some comments claiming that post-Cold War era has witnessed a second generation peace operations -as noted in the following sections (2.2.1.)- and the UN peace initiatives gained deeper and broader dimensions. Arguments against this approach condense mainly in two fields. The first claim is that the UN's post-Col War interventions which also includes trials were triggered by realistic necessities rather than moral concerns. Proponents of this claim, suggest that if moralistic approach had determined the UN interventions there should have been permanent jurisdictional institutions rather than ad hoc trials such as ITCY (International Criminal Tribunal for the former Yugoslavia) and ICTR (International Criminal Tribunal for Rwanda). Advocates of this approach backs their argument by the UN's neglects and delays on intervening in these mentioned crisis. NATO's 1999 intervention in Kosovo rather than the UN is also put forward as another evidence for the lack of moralist mechanisms for humanitarian interventions. The second and more moderate criticism on the subject points at secondary role of law institutions. According to this approach, although permanent organizations finally set, they are subjected to the UNSC's dominance. 
Reforms for betterment of the UN's peace initiatives which commenced in the eve of millennium ${ }^{2}$ however endeavour to meet moralistic requirements, the capacity to put into force is subjected to the UNSC's approval. So unless the UNSC develops moralistic stance, precautions developed at technical, tactical or operational level will have little to settle security disputes. UNSC's moralistic approach is a matter of keeping a delicate balance between sovereignty and human rights which enforce humanitarian intervention. Moralist approach sees sovereignty legitimate, as long as a state meets requirements of the UN Charter and customary law (Weiss, 2015: 80; Brown, 1992: 129-132). Moralistic obligations has forced UN to develop R2P/RtoP (Responsibility to Protect) ${ }^{3}$ mechanism. Although R2P draws a considerable degree of criticism ${ }^{4}$ and scepticism there seems to be no better way for the time being.

\subsection{Dominancy of the UNSC}

According to article 24 of the UN Charter, the primary responsibility for maintenance of international peace and security is given to the UNSC. The UNSC's monopoly on the use of force is a rather natural outcome of the realistic approach maintained by the dominating powers -the permanent members- than the need for "prompt and effective action" as noted in the Charter. That this mechanism for stability is rooted in great power interests rather than legal commitments should cause no surprise; de facto action has been a regular and primary feature of sustainable international systems in every historical period.

The UN structure was based on the consideration that one of the main reasons for the collapse of the international system of the League of Nations was its failure to adequately integrate great powers in the collective decision making process. According to the League Covenant, non-permanent members also had a veto. By revision of October 2, 1936 the Council had raised the nonpermanent membership from eleven to twelve while keeping the permanent members at four (France, Italy, Japan and UK) (Lowe, Roberts, Welsh and

2 See, (Brahimi Report, 21 August 2000); (UN, 2009); (UN, 2010a); (UN, 2010); (GA64thS, 2010); (GA70thS, 2015).

3 R2P, was initiated by [UN GA 60thS, 2005: 30 (para. 138-139)] and (UN GA 63S, 2009).

4 Concerning with the criteria for humanitarian intervention, either norms spurred from experienced examples or political capabilities will be taken for granted is the most debatable issue (Arsava, 2007: 1). 
Zaum, 2008). On the other hand, the U.S. was not a member of the league, Germany's membership was limited with 1926-1933 period, and Japan and Italy abandoned the League in 1933 and 1937 respectively.

When considering the UNSC's capacity for taking decisions binding on all members of the UN regarding peace and security as noted in articles 43 and 44, the legitimacy of the use of force is determined entirely by the authority of the UNSC. With a few exceptions, this authorization has been experienced as a near-monopoly over time. The UNSC dominance has prevailed in the UN's decisions on the use of force practices and peace operations, with the notable exceptions of the General Assembly's decision on intervention to Korea in 1950 ("Uniting for Peace") 5 , and a few General Assembly or Secretary General-led peace missions in the early era of the organization, such as UNEF I (1956-1967) after the Suez crisis, the mission in West New Guinea (19621963), and the India-Pakistan observer mission (1965-1966) (Koops and MacQueen, 2015: 3). Most usually peacekeeping operations are established by the UNSC by a resolution formulated on the basis of a Secretary-General's report (Koops, MacQueen, Tardy and Williams, 2015: 3).

\subsection{Conjunctural Global Balance of Power}

While the global security situation after WWII, reflected a bipolar division, political, economic, cultural and social affairs remained fragmented and reflected developments and competition across multiple dimensions. The tension among these layers affected the interests and agendas of powers large and small contributing to the challenges for UN capacity to preserve and sustain global peace. In other words, the causal factors for conflict remained multifaceted, while the mechanism for managing conflict became reflected bipolarity. Even within the UN General Assembly there was a roughly tripartite division into pro-west, pro-east, and non-aligned groupings, but the UNSC remained two sided.

Starting from the early days of the UN, the tension between the east and the west had hindered the UN's area of initiative by two ways. First, vetoes of some permanent members of the UNSC had paralysed or at least deliberately delayed proper reactions to the threats against peace and security. Second, because of the general reluctance to jointly constitute and activate military

5 Uniting for Peace, known also as the "Acheson Plan" was adopted 3 November 1950 with UN GA resolution 377 A, by a vote of 52 to 5 was the first and the only derivation of frequent Soviet veto during 1946-50 (White, 1997: 173). 
forces responsive to the organization, collective defense remained a largely theoretical exercise.

During the Cold War era, the UN peace initiatives were bound to be limited in influence and scope, given the division of power between east and west and the role of the UNSC in minimizing escalation and revisionism. During the period between the end of the Cold War and the new millennium US dominance began to shape the UN decision-making and interventions in a fundamental way. In recent years the rise of China, the partial recovery of Russian power, and the emergence of regional balances of power have essentially reconstituted a new security model reminiscent of Cold War conditions. An analytical evaluation of these periods is submitted in the following sub-paragraphs.

\subsection{Systemic Shortfalls}

There are three key systemic deficiencies that have hindered effective UN peace operations and use of force. These are the limitations of complementary institutions on the orientation of the UNSC, the failure to constitute effective collective defence, and shortcomings in operational capacity.

\subsubsection{Limitations of Complementary Institutions' on the Orientation of the UNSC}

As mentioned above, the UN system does nothing to mitigate domination by the great powers, but instead institutionalizes it through the UNSC's permanent member structure. Bodies exist to enforce decisions by the UNSC, but not to regulate or steer its functions. The inability of the UN to respond in a timely manner to crises in Ruanda-Burundi and Bosnia-Herzegovina are two well-known examples of this dysfunction. More recently, the failure of UN security mechanisms to shape events in Syria has been near total. The UNHCR report "UN Commission of Inquiry on Syria: No end in sight for Syrian civilians", issued on 3 September 2015 notes that wholesale, repeated patterns of gross human rights violations in Syria had not been enough for the UNSC to note the threat for international security and issue calls for a ceasefire until November 14, 2015 (International Business Times, 2015).

The UN's formal security decision-making process reflects the UNSC dominance, but other aspects of this dominance manifest outside security channels. These complementary aspects of the UNSC's domination include its impressive role on the appointment of Secretary General, the appointment of judges to the International ICJ (Court of Justice) and the ICC (International 
Criminal Court) and judges and prosecutors for other ad hoc international criminal tribunals, and the admission of new members to the UN. Concerning with the UN's peace initiatives, although sophisticated organs like DPKO (Department for Peace Keeping Operations), DPA (Department of Political Affairs), DFS (Department of Field Support), the UN Peacebuilding Commission are established, none of them are authorized to act without Secretary General's guidance which could only be applicable subjected to the UNSC's acceptance. This network of authorities renders significant provisions of the Charter dependent upon the devastating power and responsibility of the UNSC - particularly to the permanent members -and makes it virtually impossible for countries or organizations outside the UNSC to initiate or organize solutions or measures in support of global peace and security that may have broad resonance outside the UNSC, but have one or more opponents within it.

The UN system has also less interference with the other systems on security issues. Worldwide conferences and initiatives like G-20, World Economic Forum etc. are increasingly getting busy with global security issues, but hardly influence the UN. Actually stagnation in the UN system, oblige the international community to discuss security issues on these platforms.

\subsubsection{Failure of Collective Defence}

Article 26 notes that "the UNSC shall be responsible for formulating with the assistance of the Staff Committee referred to in Article 47, plans to be submitted to the member of the UN for the establishment of the system for the regulation of armaments". According to Article 47, the Military Staff Committee shall consist of the Chiefs of Staff of the permanent members of the UNSC or their representatives. This organization was authorized to advise and assist the UNSC on all questions relating to the maintenance of international peace and security, employ and command forces placed at its disposal, regulate of armaments, and possible disarmament, consult with appropriate regional agencies, and establish regional sub-committees.

Failed efforts to activate the Committee during 1946-47 (Gungor, 2008: 8) forced the Organization to rely on ad hoc solutions, most of which were conducted either by regional security organizations or temporary coalitions. This delegation not only paralyzed the military component of collective defense, impairing the prospects of the UN for robust combined joint operation capacity, but also reduced the credibility of the Organisation and raised a high level of concern among some member states about the impartiality and suitability of the forces allocated. This deficiency reached the level of crisis 
during KFOR operation on 13 June 1999, when NATO and Russian forces were about to clash at Slatina airport in Pristina, Kosovo (Cross, 2001: 8).

Attempts to fully and effectively operationalize Article 43-45 of the Charter likely would have required creation of standing the UN armed forces, a proposition that never progressed to tangible outcomes. ${ }^{6}$ The UN's failure to establish collective defence also prevented the establishment or maintenance of a standing and/or rapid reaction peace force. Restructuring of the UN with a dedicated bureaucracy for peacekeeping after 1992 did not produce substantive change. Considering the other limitations on command, control, communication, early warning, operational planning, logistics and other factors, this deficiency represented an insuperable stumbling block to the organization's operational capacity.

Political divisions exacerbated these structural problems. The lack of solidarity or common policy positions delayed response to crises in Somalia, Bosnia, Rwanda and Syria, causing financial, material and manpower shortfalls that made it impossible to prevent heavy humanitarian losses. A flawed decision-making process and other structural limitations coupled with political disunity ensured an incapacity for effective common action, let alone collective defence or security.

\subsubsection{Operational Capacity Limitations}

The delegation of operational responsibility to regional security organisations or ad hoc coalitions is not a choice for the UN but a necessity, due to the complexity of UN's structure, processes, and its capacity limitations. This shifting of operational responsibility, coupled with a broadly conceived area of initiative for the organization, reduces its oversight and authority over operations.

Peace operations and other use of force operations may be seen as separate in theory but are inseparable in practice for the establishment of stable and enduring security conditions. Historical experience shows that the use of force operations subsequently requires some type of peace operation. Similarly only a limited portion of overall peace operations can be neatly conducted within the framework of "traditional peacekeeping" - in other words within the principles of consent, impartiality, non-use of force other than self-defence (UN, 2008: 31-35; UN, 2012 a: 60-72). As is detailed in the following section

6 Efforts to establish a standing UN armed forces commenced with the first Secretary General Trygve Lie and lasted until millennium with a considerable decrease after 1995. For more information see, (Adams et al, 2008: 99-130). 
(2.1.), the UN use of force and peace operations are complex in nature and by design.

Redundant arguments on the UN's authority over and monopoly on the legitimate conduct of peace operations may occupy intellectual or academic arenas, but they are rendered rather moot and sterile by the more fundamental problem of insufficient the UN capacity for conducting complex peace operations.

Concerning authorization of the UN for peace operations, although these operations are not specifically defined in the UN Charter, initiatives in this context are integral to both the responsibilities in Chapter VI (Pacific Settlement Disputes) and Chapter VII (Action with Respect to Threats to the Peace, Breaches of the Peace and Acts of Aggression). ${ }^{7}$ Indeed, as the sole organisation which has the right to intervene with military forces, it is curious that the UN does not use initiatives like peace operations before situations escalate to a level requiring more substantial use of force. Comments implying that the gap in the Charter locating peace operations somewhere between Chapter VI and VII or envisaging them as "Chapter $61 / 2$ operations" create a degree of confusion over the basis of authorization which can be misleading (Lowe et al., 2008: 7).

Concerning the domination of the UN on peace operations, although theoretically the UN does not have a monopoly on conducting peace operations, it is the single most important institution in the field, having carried out many more operations over more decades than any other actor. Other actors like EU, ECOWAS (Economic Community of West African States), AU (African Union), NATO conduct peace operations, and use the delegated legitimacy of the UN to do so (Koops et al., 2015: 1). So counter-arguments addressing these actors' competency should be considered within the context of capacity, not the legitimacy or availability to the international law.

\section{Analysis of the UN's Use of Force and Peace Operations}

As noted in general terms in the previous section, the concept of UN use of force and peace operations is complex in nature and shows every indication

7 The UNSC's powers to establish peacekeeping operations were the key point of contention that led to the International Court of Justice (ICJ)'s Advisory Opinion of July 20, 1962 in the Certain Expenses of the UN case. ICJ Reports 1962, 163, and 175-7 (Lowe et al., 2008: 7). 
based on current trends of being even more problematic in the future. This distinct characteristic of UN's use of force and peace operation concept is shaped by the mission and the goals of the organization, the changing nature of the risks, threats, and conflicts as well as transformations in the global balance of power, and the world order. While the mission and the goals of the organization remain constant, other factors vary and interact each other. The need for managing these deeply intermingled and amalgamated dynamics requires a comprehensive approach which can conceptualize the use of force and peace operation by considering the linkages between them. This section examines these interactions and the cause-effect relationships between current and forthcoming challenges through descriptive and statistical evaluations, pointing out the need for a better conceptual framework to guide UN activities of this kind.

\subsection{UN's the Use of Force Practices ${ }^{8}$}

The UN's use of force applications have predominantly been affected by the changing nature of the security environment, and the reflexes reflecting from the conjectural balance of power between super of great powers. Apart from that operational difficulties spurred from both the unique methodology of use of military within the UN mandate, and chances in the nature of risks and threats also frame the context.

Today's security environment is distinguished by the proliferation of non-state actors, complex and amalgamated risks and threats; it neither resembles the conditions at the founding of the UN in 1945 nor the Cold War setting (Luck, 2008: 60, 61; International Commission on Intervention and State Sovereignty, 2001: 3)

Since 1949, world has experienced over than 100 armed conflicts which can be broken into four categories (Lowe et al., 2008: 45):

- Interstate armed conflict (war between sovereign states),

- Extra-systemic armed conflict (colonial war between an external army and indigenous force),

- Intrastate armed conflict (civil war),

- Internationalized internal armed conflict (civil war with external supporters).

The number of interstate wars has always been considerably lower than the others, and the number of colonial wars dramatically decreased after 1970s. On the other hand, there occurred a considerable increase in civil wars -either

8 For a comprehensive analysis see, (Revor, 2002). 
internationalized or not- after the end of the Cold War (Lowe et al., 2008: 44). Starting from millennium, the distinction between internal and international conflicts has blurred. Since 2008, the number of major violent conflicts has almost tripled. Long-simmering disputes have escalated or relapsed into wars, while new conflicts have emerged in countries and regions once considered stable (UN GA70thS, 2015). According to HIIK, as of 2014, there were 223 conflicts saw the use of violence, the number of highly violent conflicts are 46, subdivided into 25 limited wars and 21 wars (HIIK, 2015: 15). The IISS Armed Conflict Database counts nine high-intensity conflicts and 19 medium-intensity conflicts, none of which constitute interstate wars (IISS, 2015). The relative decrease in interstate conflict denies the UN an ability to easily assess whether a given conflict poses or may pose a threat to international security. Unless a conflict becomes internationalized, the UN does not interfere in civil wars. Unfortunately, by the time a civil war becomes internationalized, it is generally too late to prevent humanitarian losses.

In civil wars -unlike the legitimate states' conventional warfare methodology- asymmetric and hybrid tools and strategies, and terrorist tactics and organisations are commonly used. Additionally, with the help of globalization, the increased availability and acquisition of military capabilities increases the devastating effects of armed conflicts. Military stalemates within a contested territory fought over by undisciplined fighters increases the likelihood of atrocities, and civilian casualties while pushing former legitimate state's military to behave immoral as -in some cases more than-its opponents.

In civil wars, granting various parties legitimacy is another dilemma for the UN. Loss of sovereignty for the ruling government turns to insurgents' gain of legitimacy. Unlike interstate armed conflicts, for civil wars, equality problem can only be solved when all the rival parties militarily exhausted and accept presence of its antagonist. This balance of power situation which could be reached after heavy losses, even requires UN's commitment for the restore of peace.

The UN, particularly the UNSC, proved unable to respond effectively to the use of force by states during the Cold War (Gray, 2008: 87). As mentioned above, the veto of the permanent members has been the major obstacle to intervention actions addressing breaches of international peace. During the period of 1946-2016 a total of 192 vetoes were used in the UNSC, nearly 76\% (146 vetoes) from 1946-1990 (UN Documentation). The veto and the threat of veto not only prevented the UNSC from express reference to article 42 (occasionally allowing Article 41 but preferring to use the language of Article 39), it also caused decisions which damaged its prestige as an institution. During the Cold War, UNSC ignored its responsibilities in Hungary (Revolt in 
Budapest 1956), Czechoslovakia (Prague Spring in 1968), and Afghanistan (1979), and it could only react four years after Iran-Iraq war broke out with 6 officers of UNTSO (United Nations Truce Supervision Organization), and unanimous decision of the UNSC (Res.598); a call for ceasefire took 7 years (1987). Up to 1990, the UN employed sanctions to only two states: Rhodesia (Res. 221, 232, 253, 277, 409, 460) and South Africa (Res. 418). Except for the Korea (Res. 83, 84) and Rhodesia (Res. 221) decisions, there were no UNSC resolutions for authorization of military operations. ${ }^{9}$

The first two decades of the post-Cold War era had witnessed a political climate which presented a growing and sharp contrast between an overactive UNSC and a rather stagnant UN GA (Nasu, 2009: 2). With the end of the Cold War, criticism against the UN became far more direct than had been the case previously, based on the concerns that UNSC had become too active. The power vacuum that emerged with the demise of the bi-polar world order prompted the UNSC to behave more like an activist agency for liberal change and reform, but this liberalism never extended to reforms in the structural or the constitutional dimension. This era bought more emphases on concepts of preemptive strike, humanitarian intervention, ${ }^{10}$ status of occupying forces and wide interpretation of Article 39, enabling the international community to intervene in civil wars in Somalia and Yugoslavia; respond overthrow of democratically elected regimes, such as in Haiti; and mitigate the collapse of law and order as in Albania (Gray, 2008: 89). Since 1990, there has been a sharp increase both in the sanctions and use of force authorization. During this period, UN initiated a total of 58 sanctions in 19 cases (Cortright et al., 2008). Since 1990, the UNSC has authorized more than 25 military operations.

Starting with the first decade of the millennium, the return of Russia to the global political arena revived a version of the UNSC's cold war syndrome. This return has created two major consequences: limiting western initiatives, and disabling the UN authority for actions against Russian interests. During the Arab Spring in Libya, France flouted the UN's no-fly-zone resolution ${ }^{11}$ with bombardment exceeding the purpose of securing civilians. This intervention was institutionally backed and conducted by NATO forces, dividing the country, encouraging the $\mathrm{Al}$ Qaeda terrorists and the other affiliates of

9 There is also an academic legal approach which regards the Coalition military action against Iraqi armed attack to Kuwait in 1991 came under the provisions of Chapter VII of the UN Charter (McCoubrey and White, 1995: 4).

10 For humanitarian intervention see, (Weiss, 2015)

11 UNSC Resolution 1973 was adopted by a vote of 10 in favour to none against, with 5 abstentions (Brazil, China, Germany, India, Russian Federation). 
extremist terrorist organizations, favouring redistribution of trade contracts and natural resources for some intervening countries (and against the interests of China and Turkey, for instance). This experience caused Russia and China to be highly skeptical of later resolutions to stop civilian deaths in Syria. Since 2011, Russia and China have vetoed the UNSC resolutions concerning Syria four times.

On the other hand, after the Cold War Russia's strategic moves against Georgia in 2008, followed by the Crimea and Ukraine in 2014, and finally against Syrian opposition in 2015 were neither delayed not mitigated by the UN efforts. The new era contains some characteristics of the Cold War tensions, and presents a picture of multi-polar world order with bi-polar military force composition (and competition). In this environment, international issues are likely to remain unresolved if a by-pass mechanism cannot be developed to nullify the impasse in the UNSC.

Operational difficulties stem from two main reasons: the first is the complex nature of the UN's intervention methodology, the second is the changing nature of the risks, threats and the armed conflicts.

The UN's use of force practices are markedly distinct from traditional war methodology. For the UN type use of force practices, the end states are limited to denying the belligerent the ability to execute an aggressive act rather than overwhelmingly defeat/destroy enemy forces or occupy its territory. Diplomatic initiatives for peaceful settlement before the outbreak of violence and crisis management activities afterward take a great portion of the total effort and time. Gradual use of force is the most determinant characteristic of these types of operations. In this context, call for non-aggression, impose of sanctions, embargoes and siege, show of flag or force for commitment are measures put into force before kinetic military action. Overseas deployment of forces, multinational force structure, long duration of stay after the operation for the normalization of the security environment, and the transfer of responsibility to a peace force are other features that differ from conventional operations undertaken by great powers outside the UN context.

Difficulties for the UN's use of force applications stem from the complexity of contemporary methods in fighting and waging war, and this is not limited to civil wars-as mentioned above. Current and forthcoming threats center on global terrorism and the other types of asymmetric warfare, including cyber attacks and a variety of information warfare strategies. Additionally, the acquisition of weapons of mass destruction by rough states or non-state actors does and will require more sophisticated reactions for the UN. Unless these threats become tangible and show target as ISIS does, or international 
situational awareness, and sufficient commitment developed, the UN has very little to do with them.

\subsection{UN's Peace Operations}

\subsubsection{Consequences of Political Conjectural Changes}

As for the use of force applications, the UN peace operations during the Cold War, were heavily constrained by superpower power struggle in and outside the Security Council (Koops et al., 2015: 6). Until 1988, when clear indications of the end of the Cold War became obvious, the UN could only come bring to fruition 13 peace operations (UN, 2012 b). These operations were limited in objective and scope to stopping the further escalation of conflicts, ${ }^{12}$ assisting the process of decolonization, ${ }^{13}$ focusing on monitoring ceasefire agreements, ${ }^{14}$ ceasefire lines/demilitarized areas, ${ }^{15}$ and confidencebuilding activities ${ }^{16}$ to preserve peace processes for various conflicts. This period also witnessed only a small portion (one in seven) of the total of $36 \mathrm{UN}$ missions, institutions or administrations that fall within the peace operations concept but are not considered peacekeeping operations per se. ${ }^{17}$

With the end of the Cold War, a considerable increase both in the number and the spectrum of peace operations has been witnessed (Kolb, 2010: 93). The collapse of the Socialist bloc triggered the fragmentation of some multinational states as Yugoslavia (in 1991). Additionally, the fall of the Eastern bloc removed a major element that muted or limited regional confrontations, and flattened the 'hierarchy' of the international system, giving states a wider area of initiative and also encouraging some to pursue expansionist ambitions, as did Iraq in 1990.

12 As an example see, Lebanon, UNOGIL (United Nations Observation Group in Lebanon) (June - December 1958), (UNSCR 128: 1958).

13 As an example see, Republic of the Congo, ONUC (United Nations Operation in The Congo) (July 1960 - June 1964) (UNSCR 143: 1960).

14 As an example see, Palestine, UNTSO (United Nations Truce Supervision Organization) (May 1948 - present) (UNSCR 50: 1948).

15 As an example see, Cyprus, UNFICYP (United Nations Peacekeeping Force in Cyprus) (March 1964 - present) (UNSCR 187: 1964).

16 As an example see, Lebanon, UNIFIL (United Nations Interim Force in Lebanon) (March 1978 - present) was (UNSCR 425: 1978).

17 See, (Lowe et al., 2008: Appendix 2). 
During this period, 58 peace operations have been conducted, comprising nearly $82 \%$ of the total of 71 operations since 1945 . During the first decade after the Cold War (1988-1999), 40 peace operations took place. The period after the millennium witnessed 16 peace operations. The return of the Russia to the political scene as a global power, however, has created stagnation in UN's use of force practices and setbacks for the UN peace operations, particularly in its periphery and the Middle East. As for the UN use of force practices, it is not easy to assert that this return has initiated a decrease in the UN peace operations in total. In fact;

"There has been an increase in the proportion of armed conflicts that receive peacekeepers. During the Cold War, peacekeepers were deployed within five years of a conflict onset in a little less than a quarter (24\%) of all cases. The proportion increased to a little over half $(51 \%)$ in the postCold War period, with progressive increases in the 1990s (41\%), 2000s (64\%), and 2010s (83\%), showing that the increase was not simply a function of the ending of the Cold War but was strengthened and sustained by factors that emerged after its end" (Bellamy and Williams, 2015: 15).

The UN's unpreparedness for this dramatic and mostly unexpected change in the world order pre-determined inefficiencies of the post-Cold War era peace operations to properly react and manage international or internationalized crisis. Compared to the Cold War era peace operations, which were framed by the principles of consent-impartiality- minimum use of force and by the constrained objectives mentioned above - the second phase operations represented a new generation with higher expectations, deeper and broader in scope. Unfortunately, these expectations for the most part have not been sufficiently met.

Currently, 16 peace operations are ongoing, 11 of which were initiated after 1990. As of 2015 a total of 128.000 personnel from 122 states are directly serving for a total of 39 peace operations and missions (UN GA70thS, 2015: 2); approximately 90,000 of which are military, 13,500 police, and 16,700 civilian. The annual cost of these operations is $\$ 8.27$ billion (UN PKOs Fact Sheet, 2015). These figures are higher than at any time in the history of the UN, but the costs have not been mirrored by successful results.

\subsubsection{Operational Difficulties}

Structural and institutional deficiencies together with conjunctural obstacles contribute to the operational difficulties of the UN peace operations. Additional operational demands driven by current and emerging trends in the 
field for sustainable safety, security, stability also add to operational difficulties. Major operational difficulties are six-fold.

Firstly, peace force availability both for rapid reaction, and quality of force is a major operational hindrance. As experienced very frequently in the near history as Yugoslavia, Rwanda, and Somalia in 1990s, delayed and initially poor activation of a peace operation is not only a result of formal decision-making processes or political debate, but also stems from the UN operational deficiencies both caused by the lack of rapid reaction or available ready forces, and tactical and logistical insufficiency of the deployed troops (Koops et al., 2015: 7). Although, DPKO and DFS have recently developed a strategic agenda for uniformed capability development that prioritizes rapid deployment, standing capabilities; increased mobility of all units in-theatre including aviation support; enhanced medical support; IED survivability measures; improved information and analysis; expertise to address transnational threats such as organized crime, and planning and implementation, over the medium term, it is not likely that these capabilities can be generated in the near future (Statement..., 2014: 6).

The UN generally is inclined to accept troops from various participants which do not meet all requirements of the mission, because they are easy to obtain and easier for the participating country to part with. A great majority of the participants do not meet mission requirements because of the reasons either spurred from internal institutional shortfalls as lack of peacekeeping or military culture and limited operational capabilities or resulted from inadequacies on particular requirements specific to the mission as gender, ethnic or religious identities or expertise spectrum of the contributing troops. So not only the quantitative but also the qualitative adequacy inherently limits the success of the mission. In that context, troops' advocacy of the values that the UN promotes is essential for the success of the UN use of force or peace operations.

Secondly, management of broadening mission requirement creates a heavy burden for peace operations. A concept of peacekeeping applications limited to the goals of stopping the further escalation or spread of conflicts on the one hand or implementing a truce through a process of extended monitoring, observation, and ceasefire applications is insufficiently broad given the modern expectations of governments and publics about maintenance and management of peace and security. In addition to peacekeeping, peace operations may include: ${ }^{18}$

18 See, (UN, 2008: 17-25), and (U.S. Joint Chief of Staff, 2012: 1-7-1-9) 
- Conflict Prevention that employs complementary diplomatic, civil, and, when necessary, military means, to monitor and identify the causes of conflict, and take timely action to prevent the occurrence, escalation, or resumption of hostilities.

- Peace enforcement that compels compliance with resolutions or sanctions designed to maintain or restore peace and order.

- Peace making that arranges an end to a dispute and resolves issues that led to it with the process of diplomacy, mediation, negotiation, or other forms of peaceful settlements that.

- Peace building that strengthens and rebuilds governmental infrastructure and institutions in order to avoid a relapse into conflict by predominately diplomatic and economic stability actions.

Too often the UN has found that it does not have tools adequate to the broader set of tasks associated with peace operations. Some of these tasks have exceeded the resources -including time- available to the UN decision makers and force contributing nations. On the other hand, in some cases the tasks have clearly been within the capacity of available or obtainable forces, but the analytical linkage between crisis and possible response has not been rigorously conducted. Even in cases where there is no political paralysis brought from a neighboring great power state with a contrary interest, lack of preparation and conceptual definition have been insuperable obstacles. As result, efforts have been fragmented and forces unequal to the task (UN GA70thS, 2015: 2).

Requirements for varying types of operation with sophisticated expertises is another major operational difficulty. Peace operations may also include MARO (mass atrocity response operations), humanitarian relief and assistance operations, and "other than war operations". 19 Tactics, techniques and procedures for peace operations may include; monitoring, observation, reconnaissance, surveillance, early warning, preventive deployment, protected area implementations (line of demarcation or ceasefire line, buffer zone, zone of separation, demilitarised zones, safe zones, safe havens, no-fly-zones, nodrive-lines), area security, shape-clear-hold-build, partner enabling, containment, perpetrator defeat, refugee or internally displaced persons control and rehabilitation, DDR (disarmament demobilization and reintegration), ${ }^{20}$ rehabilitation, electoral assistance, human rights monitoring, demining, diplomacy, deterrence, enforcement of sanctions, security sector reform and

19 See, (JP 3-07, 1995).

20 For more information about DDR see, (UN, 2010 a). 
training, restoration and maintenance of law and order, transition of transfer of authority, economic stabilisation etc (UN, 2003: 60-64).

These missions require more sophisticated expertise than ordinary peacekeepers, and enhanced capabilities for managing and coordination of these institutions. Although defined goals meet requirements for multidimensional UN peace operations, chances for their realisation seems quite low because of practical burdens such as low literacy, poor professional training, low-level standardisation, and limited financial ${ }^{21}$ support etc. Except for NATO, EU ${ }^{22}$, WEAG and some of OSCE members, lack of manpower qualification and expertise is common also for nearly all civilian positions. When considered that the contributing nations to the UN peace operations with greatest motivation are states with undeveloped or developing economies which suffer from severe institutional or professional limitations, the problematic situation become more visible. This phenomenon affects military and civilian professions, and can best be illustrated with reference to deploying police forces. Since the first use in 1960 (Congo, ONUC) there has been a considerable increase in use of police forces both in number and specializations. Currently, around 3,000 police are employed in 19 UN peacekeeping missions, seven of which are peacekeeping operations. UN police expertise are divided into over 40 branches. Despite some hopeful steps, imbalance in the gender composition of the police employment is another problematic issue. ${ }^{23}$ In that regard, Secretary-General Ban Ki-moon endorsed the Global Effort initiative in August 2009, weeking to increase the deployment of female police peacekeepers to 20\% by 2014 (UN Police, 2012: 89-109). There was an increase, but it only amounted to about 10\% (UN Police, 2014: 49).

Requirements in varying types of operations for a variety of sophisticated expertise also creates doctrinal challenges. It has been recognized that no two peace operations are alike, that each is distinct and unique. These missions require innovation, flexibility, initiative and moral courage on the part of the individuals involved. The difficulty lies in the capturing doctrine without being dogmatic and rigid, which is easy to say but difficult to apply (The CP, 2002: $16,17)$.

The fourth major operational difficulty is the necessity to cope with multi-party rival groups in multi-dimensional risks and threat environment. The

21 For financial limitations see, (Keskin, 1998: 179-182)

22 For the EU and Turkey's civilian contribution to the UN peace operations see (Hürsoy, 2006).

23 See, (UNSCR 1325, 2000); (OGASI a); (OGASI b: 2005). 
complex nature of today's confrontations which have historical, social, economic, and ethnic roots with multi-party rival groups makes peace operations increasingly difficult. Additionally, physical operational conditions subject UN personnel to threats ranging from chemical and biological agents to highly epidemic diseases as Ebola virus, endangers sustainability of peace operations. Extensive use of mines and IEDs also exacerbates security concerns (Statement..., 2014: 2-5).

Complexity of multi-dimensional peace operations with multiple players and partners is another major issue. Peace operations also require co-operation and interoperability with UN field staff entities and partners.

The field staff of UN entities, among them UNHCR (the Office of the United Nations High Commissioner for Refugees), WFP (the World Food Programme), UNICEF (the United Nations Children's Fund), OCHA (the Office for the Coordination of Humanitarian Affairs), UNDP (the United Nations Development Programme), and OHCHR (the Office of the United Nations High Commissioner for Human Rights), often work closely with peacekeepers. Additionally, in many mission areas, a SRSG (Special Representative of the Secretary-General) and diplomatic staff are also appointed (UN, 2003: 2).

Partners include countries contributing personnel, other member states, donors; regional military or police forces, regional and sub-regional organizations, Bretton Woods institutions; inter-governmental organizations, NGOs (non-governmental organizations), and the international media (UN, 2003: 11).

Activities at such a broad scope and depth requires multidimensional, comprehensive engagement with military, civil, technical, political, administrative, judicial, engineering, medical sophistications, and effect-based operation capability which generally exceed the current and expected future capacity of UN peace operations forces and organizations.

Finally individual manipulations' devastating effects jeopardise success of peace operations. A failure on the part of any peace operations participants or contributors erodes the UN's acceptance and authority. Unprofessional or illdisciplined personnel abuses -even sporadic- may endanger success of the whole operation. In some cases some UN affiliated or authorised or recognises organisations -particularly some INGOs/NGOs- systemically waste UN resources. This kind of systemic unlawful exploitations also delay reaching the desired end-state while prolonging UN's presence than needed. 


\section{Assessment}

Critiques of the systemic shortfalls of the UN are not limited to those mentioned above (1. Theoretical Framework), but those cited should be enough to clarify that the UN system remains too linear, too opaque, insufficiently dynamic and adaptive, and is likely not able to transform on its own, absent top-down reform or a generation of conscious refinement of sub-systems. This poor function of the system at present both reduces synergy and increase risks for entropy. Any system can only survive as long as it preserves its own identity; be coherent with the environment or develop precautionary measure; and sustain its missions timely and effectively based upon its goals. ${ }^{24}$ From that point of view, it is no exaggeration to note that despite its monopoly position as an organization founded to help maintain a global balance of power, the UN as a system has deficiencies of structure, function, and capacity sufficient to call into doubt its future survival.

Current international system is highly differentiated from the setting of 1945, which makes security issues and breaches of international peace and stability more difficult to resolve. International mechanisms other than the UN are not at the point to take over the UN's roles and responsibilities. However the UN's operational deficiencies, particularly regarding the use of force applications, consistently render the organisation dependent on regional security organisations, ad hoc coalitions or contributing nations. Stagnation in the use of force practices overburdens peace operations, and increases their responsibilities and expectations placed on the UN peace institutions and forces capabilities. The necessity of improving systems to manage the use of force problems through peace operations is pressing, and the current situation obliges the UN to manage conflicts with less appropriate tools. Some measures and projects for improving the system of the UN peace operations are promising, but no one to date has proposed reforms that address structural deficiencies and problems. It is not clear whether this is a failure of creativity or a failure of will, but it clearly is a failure.

In order to meet future challenges, there is a demanding need for action mainly on two institutional issues. These are resolution of conflict among state sovereignty and human rights and justice, and enhancement of operational capacity for meeting success criteria.

The situation requires a renewed focus on prevention and mediation with a stronger determination of the UN - either within the UNSC or UN General Assembly- with extensive coordination and cooperation. It also requires

24 See, (Parsons, 1968). 
stronger regional-global partnerships enforced by institutionalized and systematized tactics, techniques, planning and operational procedures, as well as and new ways of planning and conducting the United Nations peace operations to make them faster, more responsive, more comprehensive, and more accountable. In short, the international system badly needs more appropriate tools and more effective mechanisms to avoid repetitive catastrophes for countries and people in conflict (UN GA70thS, 2015: 3).

\section{Bibliography}

Arsava, Fusun (2007), "BM Güvenlik Konseyi'nin İnsan Haklarını Koruma Rolü ve Güvenlik Konseyi'nin Yetkilerinin Dayanağı ve Sınırları”, Uluslararası Hukuk ve Politika, 4 (13): 1 16 http://www.usakgundem.com/ftp/article/103.pdf (20.04.2016).

Bellamy Alex J. and Williams Paul D. (2015), "Trend in Peace Operations, 1947-2013", Koops, Joachim, Norrie MacQueen, Thierry Tardy, and Paul D. Williams (Eds.), The Oxford Handbook of United Nations Peacekeeping Operations (United Kingdom: Oxford University Press): 13-42.

Bertalanffy, Ludwig Von (1968), General Systems Theory: Foundations, Development, Applications (New York: George Braziller, INC): 32, http://monoskop.org/ images/7/77/Von_Bertalanffy_Ludwig_General_System_Theory_1968.pdf (19.01.2016).

Boulden Jane (2015), "United Nations Operation in the Congo (ONUC)", Koops, Joachim, Norrie MacQueen, Thierry Tardy, and Paul D. Williams (Eds.), The Oxford Handbook of United Nations Peacekeeping Operations (United Kingdom: Oxford University Press): 160-170.

Brahimi Report (21 August 2000), General Assembly Fifty-fifth session, Item 87 of the provisional agenda "Comprehensive review of the whole question of peacekeeping operations in all their aspects".

Brown Chris (1992), International Theory: New Normative Approaches (New York: Harvester Wheatsheaf).

Cortright David, Lopez George A. and Gerber-Stellingwerf Linda (2008), "Appendix 4: UNAuthorized Sanctions, 1945-2006", Lowe, Vaughan, Adam Roberts, Jennifer Welsh, and Dominik Zaum, (Eds.), The United Nations Security Council and War: The Evolution of Thought and Practice since 1945 (United Kingdom: Oxford University Press): 678-687.

Cross Sharyl (2001), "Russia and NATO Toward the 21st Century: Conflicts and Peacekeeping in Bosnia-Herzegovina and Kosovo", NATO/Academic Affairs 1999-2001, http://www.nato.int/acad/fellow/99-01/cross.pdf (19.01.2016).

Findlay, Trevor (2002), UN Use of Force in Peace Operations (Solna, Sweden: SIPRI Oxford University Press), http://books.sipri.org/files/books/SIPRI02Findlay.pdf (19.01.2016).

Gray, Christine (2008), "The Charter Limitations on the Use of Force: Theory and Practice", Lowe, Vaughan, Adam Roberts, Jennifer Welsh, and Dominik Zaum (Eds.), The United Nations Security Council and War: The Evolution of Thought and Practice since 1945 (United Kingdom: Oxford University Press): 86-98.

Güngör, Uğur (2008), "Today’s Peace Operations”, The Journal of Security Strategies (Istanbul: Turkish Staff College), 4 (8): 7-20. 
HIIK (The Heidelberg Institute for International Conflict Research) (2015), Conflict Barometer 2014 Heidelberg, http://www.hiik.de/en/konfliktbarometer/pdf/ConflictBarometer_2014.pdf (19.01.2016).

Hopkins, Raymond F. (1995), "Anomie, System Reform, and Challenges to the UN System", Esman, Milton J. and Shibley Telhami (Eds.), International Organizations and Ethnic Conflict (Ithaca and London: Cornell University Press): 72-97.

Hürsoy, Siret (2006), "Civilian Contributions of the European Union and Turkey within the Framework of Restructuring the United Nations Peace Operations", Ankara Üniversitesi SBF Dergisi, 61 (1): 201-222.

IISS (International Institute for Strategic Studies) (2015), Armed Conflict Database, https://acd.iiss.org/ (19.01.2016).

International Commission on Intervention and State Sovereignty (2001), The Responsibility to Protect (Ottawa: International Development Research Centre).

Joint Chief of Staff (1995), Joint Publication 3-07: Joint Doctrine for Military Operations Other Than War (Washington D.C.: U.S. Joint Chief of Staff), http://www.bits.de/NRANEU/others/jpdoctrine/jp3_07.pdf (19.01.2016).

JP 3-07 [U.S. Joint Chief of Staff (2012), Joint Publication 3-07.3: Peace Operations] (Washington D.C.: U.S. Joint Chief of Staff), https://fas.org/irp/doddir/dod/jp3-07-3.pdf (19.01.2016).

Keskin Ata, Funda (1998), Uluslararası Hukukta Kuvvet Kullanma: Savaş, Karışma ve Birleşmiş Milletler (Ankara: Mülkiyeliler Birliği Vakfı Yay.).

Kolb Robert (2010), An Introduction to the Law of the United Nations (Oxford and Portland Oregon: Hart Publishing).

Koops, Joachim, MacQueen Norrie, Tardy Thierry, and Williams Paul D. (Eds.) (2015), The Oxford Handbook of United Nations Peacekeeping Operations (United Kingdom: Oxford University Press).

Koops, Joachim and Tardy Thierry (2015), "The United Nations' Inter-Organizational Relations in Peace Operations", Koops, Joachim, Norrie MacQueen, Thierry Tardy, and Paul D. Williams (Eds.), The Oxford Handbook of United Nations Peacekeeping Operations (United Kingdom: Oxford University Press): 60-77.

Kreiter, Marcy (November 14, 2015), "Syria Civil War: World Leaders Call for Ceasefire, 18-Month Transition", International Business Times, http://www.ibtimes.com/syria-civil-war-worldleaders-call-ceasefire-18-month-transition-2184695 (19.01.2016).

Lowe, Vaughan, Roberts Adam, Jennifer Welsh, and Zaum Dominik, (Eds.) (2008), The United Nations Security Council and War: The Evolution of Thought and Practice since 1945 (United Kingdom: Oxford University Press).

Luck, Edward C. (2008), "A Council for All Seasons: The Creation of the Security Council and its Relevance Today", Lowe, Vaughan, Adam Roberts, Jennifer Welsh, and Dominik Zaum, (Eds.), The United Nations Security Council and War: The Evolution of Thought and Practice since 1945 (United Kingdom: Oxford University Press): 60-85.

McCoubrey, Hilaire and White Nigel D. (1995), International Organizations and Civil Wars (Aldershot USA: Darmounth Publishing).

Nasu, Hitoshi (2006), International Law on Peacekeeping: A Study of Article 40 of the UN Charter (Lieden: Boston, Martinus Nijhoff Publisher).

OGASI a (Office of the Special Adviser on Gender Issues), http://www.un.org/womenwatch/ osagi/wps/ (19.01.2016) 
OGASI b (2005), Woman and Elections: Guide to Promoting the Participation of Woman in Elections (New York: UN), http://www.un.org/womenwatch/osagi/wps/publication/Women AndElections.pdf (19.01.2016).

Parsons, Talcott (1968), The Structure of Social Action (New York: The Free Press McMillian Publishing).

Roberts, Adam (2008), "Proposals for UN Standing Force: A Critical History", Lowe, Vaughan, Adam Roberts, Jennifer Welsh, and Dominik Zaum, (Eds.), The United Nations Security Council and War: The Evolution of Thought and Practice since 1945 (United Kingdom: Oxford University Press): 99-130.

Statement of Under-Secretary-General for Peacekeeping Operations Hervé Ladsous Debate of the Fourth Committee on Peacekeeping (28 October 2014), http://www.un.org/en/ peacekeeping/documents/USG-Ladsous-4C-Statement28102014.pdf (19.01.2016).

The CP (The Challengers Project) (2002), Challenges of the Peace Operations: Into the $21^{\text {st }}$ Century Concluding Report 1997-2002 (Stockholm: Elanders Gotab).

UN (2003), Handbook on United Nations Multidimensional Peacekeeping Operations (New York: Peacekeeping Best Practices Unit DPKO), http://www.unrol.org/files/Handbook\%20 on\%20Multi-Dimensional\%20Peacekeeping.pdf (19.01.2016).

UN (2008), United Nations Peacekeeping Operations Principles and Guidelines (New York: DPKO and DFS), http://www.zif-berlin.org/fileadmin/uploads/analyse/dokumente/UN_Capstone_ Doctrine_ENG.pdf (19.01.2016).

UN (2009), A New Partnership Agenda, Creating a New Horizon for UN Peacekeeping (New York: UNDPKO and DFS), http://www.un.org/en/peacekeeping/documents/newhorizon.pdf (10.04.2016)

UN (2010 a), The New Horizon Initiative: Progress Report No. 1 (New York: UNDPKO and DFS), http://www.un.org/en/peacekeeping/documents/newhorizon_update01.pdf (10.04.2016)

UN (2010 b), United Nations, in Peace Operations a Retrospective (New York: DOPOs Office of Rule of Law and Security Institutions).

UN (2011), The New Horizon Initiative: Progress Report No. 2 (New York: UNDPKO and DFS), http://www.un.org/en/peacekeeping/documents/newhorizon_update02.pdf (10.04.2016).

UN (2012 a), Civil Affairs Handbook [New York: UNDPKO (Department of Peacekeeping Operations) and DFS (Department of Field Support)].

UN (2012 b), The Year in Review 2012 United Nations Peace Operations, http://www.un.org /en/peacekeeping/publications/yir/yir2012.pdf (19.01.2016).

UN Documentation, "Veto List”, Dag Hammarskjöld Library Research Guides, http://research.un.org /en/docs/sc/quick (19.01.2016).

UN PKOs (United Nations Peacekeeping Operations) (October 31, 2015), Fact Sheet http://www.un.org/en/peacekeeping/documents/bnote1015.pdf (19.01.2016).

UN Police (United Nations Police) (2012), On Duty for Peace 2008-2012 (New York: UN DPKO), http://www.un.org/en/peacekeeping/publications/12\%2053015_UNPOL\%20booklet.pdf (19.01.2016).

UN Police Magazine (2014), (New York: DPKO), www.un.org/en/peacekeeping/sites/police (19.01.2016).

UN GA60thS (General Assembly, Sixtieth session): Items 46 and 120 of the agenda (24 October 2005), "Resolution adopted by the General Assembly, 2005 World Summit Outcome", http://www.un.org/en/preventgenocide/adviser/pdf/World\%20Summit\%20Outcome\%20Do cument.pdf\#page $=30$ (10.04.2016) . 
UN GA63S (General Assembly, Sixty-third session): Items 44 and 107 of the agenda (12 Januray 2009), "Implementing the responsibility to protect", http://www.un.org/en/ga/search/ view_doc.asp?symbol=A/63/677 (10.04.2016).

UN GA64thS (General Assembly, Sixty-fourth session): Items 33 and 146 of the agenda (January 26, 2010), "Global field support strategy, Report of the Secretary-General", http://www.un.org/en/ga/search/view_doc.asp?symbol=A/64/633 (10.04.2016).

UN GA70thS (General Assembly, Seventieth session): Items 56, 57 and 123 of the provisional agenda) (September 2, 2015), "The future of United Nations peace operations: implementation of the recommendations of the High-level Independent Panel on Peace Operations, Report of the Secretary-General”, http://www.docfoc.com/un-security-councilreport-of-the-secretary-general-the-future-of-united-nations-peace-operationsimplementation-of-the-recommendations-of-the-hig (19.01.2016).

UNHCR (3 September 2015), UN Commission of Inquiry on Syria: No end in sight for Syrian civilians, http://www.ohchr.org/en/NewsEvents/Pages/DisplayNews.aspx?NewsID=16377 \&LangID=E (19.01.2016).

UNSCR (UN Security Council Resolution) 50 of May 29, 1948, http://www.un.org/en/ga/search/ view_doc.asp?symbol=S/RES/50(1948)

UNSCR 83 of June 27 (1950), http://www.un.org/en/ga/search/view_doc.asp?symbol=S/RES/ 83(1950)

UNSCR 84 of 7 July 1950, http://www.un.org/en/ga/search/view_doc.asp?symbol=S/RES/84(1950)

UNSCR 128 of June 11 (1958), http://daccess-dds-ny.un.org/doc/RESOLUTION/GEN/NR0/ 132/58/IMG/NR013258.pdf?OpenElement

UNSCR 143 of July 14 (1960), http://daccess-dds-ny.un.org/doc/RESOLUTION/GEN/NR0/157/32/ IMG/NR015732.pdf?OpenElement

UNSCR 187 of March 13 (1964), http://www.un.org/en/ga/search/view_doc.asp?symbol= S/RES/186(1964)

UNSCR 221 of April 9 (1966), http://www.un.org/en/ga/search/view_doc.asp?symbol= S/RES/221(1966)

UNSCR 232 of April 9 (1966), http://www.un.org/en/ga/search/view_doc.asp?symbol= S/RES/232(1966)

UNSCR 253 of May 29 (1968), http://www.un.org/en/ga/search/view_doc.asp?symbol= S/RES/253(1968)

UNSCR 277 of March 18 (1970), http://www.un.org/en/ga/search/view_doc.asp?symbol= S/RES/277(1970)

UNSCR 409 of May 27 (1977), http://www.un.org/en/ga/search/view_doc.asp?symbol= S/RES/409(1977)

UNSCR 418 of November 4 (1977), http://www.un.org/en/ga/search/view_doc.asp?symbol= S/RES/418(1977)

UNSCR 425 of March 19 (1978), http://www.un.org/ga/search/view_doc.asp?symbol= S/RES/426(1978)

UNSCR 460 of December 21 (1979), http://www.un.org/en/ga/search/view_doc.asp?symbol= S/RES/460(1979)

UNSCR 598 of July 20 (1987), http://www.un.org/en/ga/search/view_doc.asp?symbol= S/RES/598(1987) 
UNSCR 1325 of October 31 (2000), http://www.un.org/en/ga/search/view_doc.asp?symbol= S/RES/1325(2000)

UNSCR 1973 of March 17 (2011), http://www.un.org/en/ga/search/view_doc.asp?symbol= S/RES/1973(2011)

Weiss, Thomas G. (2015), "Peace Operations and Humanitarian Interventions", Joachim Koops, Norrie MacQueen, Tardy, Thierry, and Paul D. Williams (Eds.), The Oxford Handbook of United Nations Peacekeeping Operations (United Kingdom: Oxford University Press): 8792.

White, N. D. (1997), Keeping the Peace: The United Nations and the Maintenance of International Peace and Security (Manchester and New York: Manchester University Press). 